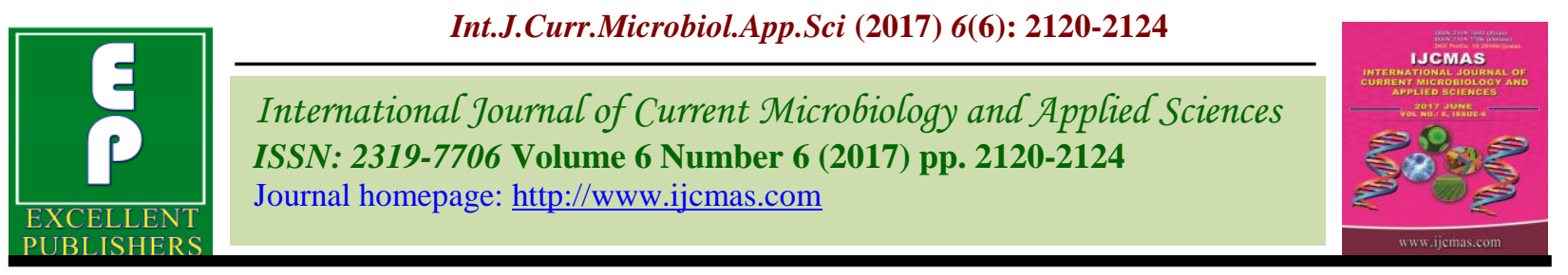

Original Research Article

https://doi.org/10.20546/ijcmas.2017.606.251

\title{
Hindrances in Functioning of Farmer Groups in Telangana State, India
}

\author{
D. Karthik*, A. Sailaja, T. Archana and Gajanand Palve \\ ICAR-NDRI, Karnal, Haryana, India \\ *Corresponding author
}

\begin{tabular}{|c|c|}
\hline & A B S T R A C T \\
\hline & \multirow{5}{*}{$\begin{array}{l}\text { The study examines the constraints faced in functioning of farmer groups in } \\
\text { Warangal District of Telangana State, using a representative sample of } 120 \\
\text { farmers from the District. Three farmer groups were selected for the study } \\
\text { Rythumitra groups }\left(\mathrm{G}_{1}\right) \text {, Farmer groups of NGO }\left(\mathrm{G}_{2}\right) \text { and Commodity interest } \\
\text { groups }\left(\mathrm{G}_{3}\right) \text {. A sample of } 40 \text { respondents from each group were selected for the } \\
\text { study. Majority of respondents from } \mathrm{G}_{1} \text { expressed that lack of village level worker } \\
\text { to assist the group management activities was major constraint. In the case of } \\
\text { respondents of } \mathrm{G}_{2} \text { majority of respondents expressed that few members deviated } \\
\text { from group adoption practices as prescribed by NGO, whereas in } \mathrm{G}_{3} \text { majority of } \\
\text { respondents expressed that uncontiguous land area of members as hindrance in } \\
\text { functioning of group. Policy makers in order to facilitate effective functioning of } \\
\text { groups must formulate appropriate policies by involving all the stakeholders so } \\
\text { that farming will be sustainable and profitable. }\end{array}$} \\
\hline Keywords & \\
\hline $\begin{array}{l}\text { Functioning, } \\
\text { Farmer Groups, } \\
\text { Telangana State } \\
\text { and Commodity. }\end{array}$ & \\
\hline Article Info & \\
\hline $\begin{array}{l}\text { Accepted: } \\
\text { 26 May } 2017 \\
\text { Available Online: } \\
\text { 10 June } 2017\end{array}$ & \\
\hline
\end{tabular}

\section{Introduction}

Traditionally, the role of extension has mainly involved technology transfer, with the village extension worker (VEW) transferring knowledge from research stations to farmers by using individual, group, and mass media methods. The present approach of extension has been asked to play a "technology development role" through linking research with community group needs and helping to facilitate appropriate technology development. In this context government agencies developed national policies for rural development and designed a policy framework to help rural people to be organized so that the delivery of services could be channelled through the various types of farmer organizations or groups. Some policies also provide blueprint structure for farmer organizations (FO) in the form of cooperatives and commodity organizations in order to provide various input, marketing, and educational services to the farmers.

Realizing importance of farmer organizations in rural development State Government has formulating several policies for mobilizing farmers into groups from the past decade through formation of Rythumitra groups (RMGs), commodity interest groups (CIGs) and women self-help groups (SHGs). But functioning of groups after formation is due to constraints such as changes resorted to shortcut methods to establish farmer organizations and groups, lack of funds etc. 
The present study focuses upon hindrances faced by farmer groups in functioning of groups so that it would help to understand the problems at grass root level which will be helpful for policy makers to formulate appropriate strategies for effective functioning of groups.

\section{Materials and Methods}

An ex post facto research design was adopted for the study as the variables chosen for the study had already occurred. The study was conducted in Warangal district of Telangana. Two Mandals in the district and two villages in each Mandal were selected randomly. From each village three types of farmer groups were selected namely G1 (Rythu Mitragroups), G2 (farmer groups of NGO) and G3 (commodity interest groups). 30 respondents were selected through stratified quota sampling from each village thus making a total of 120 respondents. Constraint analysis were carried out using frequency, percentage and ranking method.

\section{Hindrances expressed by respondents of $\mathbf{G}_{1}$ group}

It could be inferred from table 1 that majority (85.00\%) of respondents of $\mathrm{G}_{1}$ expressed lack of village level worker to assist in group management activities and adoption of technologies for which the 67.50 per cent of respondents suggested village level worker must be appointed to assist in group activities. Seventy per cent of respondents expressed poor relation with concerned functionaries for which 75.00 per cent of respondents suggested the functionaries need to maintain good rapport with groups. About 67.50 per cent of respondents expressed lack of information on market prices for which 50.00 per cent of respondents suggested that provision of market information to leader. About 62.50 per cent of respondents expressed that they were unable to attend meetings regularly for which 65.00 per cent of respondents suggested that meetings must be conducted at convenient time. Fifty seven and half per cent of respondents expressed that members were unaware of importance of collective action in agriculture for which 30.00 per cent of respondents suggested that members must be enlightened about collective action. More than thirty seven per cent felt that lack of awareness on rules, roles and responsibilities of group members for which 45.00 per cent of respondents suggested that rules, roles and responsibilities must be assigned to group members. Thirty per cent of respondents in $G_{1}$ expressed that lack of credit in time of need for which 60 per cent of respondents suggested provision of credit in time.

\section{Hindrances expressed by respondents of $G_{2}$}

It could be inferred from table 2, Majority (75.00\%) of respondents of $\mathrm{G}_{2}$ expressed few members deviated from group adoption practices as prescribed by NGO for which 72.50 per cent of respondents suggested members who deviated must be imposed penalty. 60.00 per cent of respondents expressed large group size hindering cooperation for which 52.50 per cent of respondents suggested smaller group enables effective participation.

\section{Hindrances expressed by respondents of $G_{3}$}

It could be inferred from table 3 that majority $(77.50 \%)$ of respondents expressed uncontiguous land area of members as hindrance in functioning of group for which 82.50 per cent of respondents suggested members should hail from contiguous land area. Seventy two and half per cent of respondents expressed lack of participation of group members in group meetings for which 67.50 per cent of respondents suggested members should be encouraged to participate in group meetings. 
Table.1 Hindrances expressed in by respondents of $\mathrm{G}_{1}$ group

\begin{tabular}{|c|c|c|c|c|c|c|c|c|}
\hline & & & & & & & \\
\hline $\begin{array}{l}\text { S.N } \\
\text { o }\end{array}$ & Hindrances expressed & $\mathbf{F}$ & $\%$ & $\mathbf{R}$ & $\begin{array}{|ll|}\begin{array}{l}\text { Suggestions } \\
\text { hindrances }\end{array} & \text { for } \\
\end{array}$ & $\mathbf{F}$ & $\%$ & $\mathbf{R}$ \\
\hline 1. & $\begin{array}{l}\text { Lack of information on } \\
\text { market prices. }\end{array}$ & 27 & 67.50 & III & $\begin{array}{l}\text { Provision of } \\
\text { information on market } \\
\text { to group leader. }\end{array}$ & 20 & 50.00 & V \\
\hline 2 & $\begin{array}{l}\text { Lack of credit in times of } \\
\text { need. }\end{array}$ & 12 & 30.00 & VII & $\begin{array}{l}\text { Provision of credit in } \\
\text { times of need. }\end{array}$ & 24 & 60.00 & IV \\
\hline 3 & $\begin{array}{l}\text { Poor relation with } \\
\text { concerned functionaries. }\end{array}$ & 28 & 70.00 & II & $\begin{array}{l}\text { The functionaries need } \\
\text { to establish good } \\
\text { rapport with groups. }\end{array}$ & 30 & 75.00 & I \\
\hline 4 & $\begin{array}{l}\text { Unable to attend } \\
\text { meetings regularly. }\end{array}$ & 25 & 62.50 & IV & $\begin{array}{l}\text { Meetings must be } \\
\text { according to needs and } \\
\text { interest of members. }\end{array}$ & 26 & 65.00 & III \\
\hline 5 & $\begin{array}{l}\text { Lack of village level } \\
\text { worker to assist in group } \\
\text { management activities } \\
\text { and adoption of } \\
\text { technologies. }\end{array}$ & 34 & 85.00 & I & $\begin{array}{l}\text { Village level worker } \\
\text { must be } \\
\text { group } \\
\text { activities. }\end{array}$ & 27 & 67.50 & II \\
\hline 6 & $\begin{array}{l}\text { Unaware of importance } \\
\text { of collective action } \\
\text { through groups in } \\
\text { agriculture. }\end{array}$ & 23 & 57.50 & V & $\begin{array}{lr}\text { Group members must } \\
\text { be enlightened } \\
\text { importance } \\
\text { collective action. }\end{array}$ & 12 & 30.00 & VII \\
\hline 7 & $\begin{array}{l}\text { Lack of awareness on } \\
\text { rules, roles and } \\
\text { responsibility of group } \\
\text { members. }\end{array}$ & 15 & 37.50 & VI & \begin{tabular}{|lrr} 
Rules, roles & and \\
responsibilities & of \\
members must & be \\
assigned to group \\
members.
\end{tabular} & 18 & 45.00 & VI \\
\hline
\end{tabular}

Table.2 Hindrances expressed by respondents of $\mathrm{G}_{2}$ group

\begin{tabular}{|l|l|l|l|l|l|l|l|l|}
\hline $\begin{array}{l}\text { S.N } \\
\text { o }\end{array}$ & Hindrances expressed & $\mathbf{F}$ & $\mathbf{\%}$ & $\mathbf{R}$ & $\begin{array}{l}\text { Suggestions for } \\
\text { hindrances }\end{array}$ & $\mathbf{F}$ & $\mathbf{n}=40$ & $\mathbf{R}$ \\
\hline 1. & $\begin{array}{l}\text { Large group size hindering } \\
\text { cooperation. }\end{array}$ & 24 & 60.00 & II & $\begin{array}{l}\text { Smaller groups enable } \\
\text { effective participation }\end{array}$ & 21 & 52.50 & II \\
\hline 2. & $\begin{array}{l}\text { Few members deviate from } \\
\text { the group adoption of } \\
\text { practices as prescribed by } \\
\text { NGO. }\end{array}$ & 70 & 75.00 & & $\begin{array}{l}\text { Imposing of penalty } \\
\text { for the deviating } \\
\text { members. }\end{array}$ & 29 & 72.50 & \\
\hline
\end{tabular}


Table.3 Hindrances expressed by respondents of $\mathrm{G}_{3}$ group

\begin{tabular}{|c|c|c|c|c|c|c|c|c|}
\hline S.No & $\begin{array}{l}\text { Hindrances } \\
\text { expressed }\end{array}$ & $\mathbf{F}$ & $\%$ & $\mathbf{R}$ & $\begin{array}{ll}\text { Suggestions } & \text { for } \\
\text { hindrances } & \end{array}$ & $\mathbf{F}$ & $\%$ & $\mathbf{R}$ \\
\hline 1. & $\begin{array}{l}\text { Lack of empowered } \\
\text { leaders. }\end{array}$ & 25 & 62.50 & VI & $\begin{array}{l}\text { Continuous updating of } \\
\text { knowledge and skills of } \\
\text { leaders. }\end{array}$ & 29 & 72.50 & II \\
\hline 2. & $\begin{array}{l}\text { Uncontiguous land } \\
\text { area. }\end{array}$ & 31 & 77.50 & I & $\begin{array}{l}\text { Members should hail from } \\
\text { contiguous land area. }\end{array}$ & 33 & 82.50 & I \\
\hline 3. & $\begin{array}{l}\text { Lack of support from } \\
\text { my organization to be } \\
\text { organized into a } \\
\text { group. }\end{array}$ & 27 & 67.50 & IV & $\begin{array}{l}\text { Support must be available } \\
\text { to group to be organized } \\
\text { into group. }\end{array}$ & 30 & 75.00 & VI \\
\hline 4. & $\begin{array}{l}\text { Few people dominate } \\
\text { in group. }\end{array}$ & 28 & 70.00 & III & $\begin{array}{l}\text { Homogeneity principle } \\
\text { needs to be followed in } \\
\text { group formation. }\end{array}$ & 25 & 62.50 & III \\
\hline 5. & $\begin{array}{l}\text { Lack of participation } \\
\text { of group members in } \\
\text { meetings. }\end{array}$ & 29 & 72.50 & II & $\begin{array}{l}\text { Members should be } \\
\text { encouraged to participate in } \\
\text { group meetings. }\end{array}$ & 27 & 67.50 & IV \\
\hline 6. & $\begin{array}{lr}\text { Lack of } & \text { training } \\
\text { programmes } & \text { on } \\
\text { reducing cost of } \\
\text { cultivation. }\end{array}$ & 20 & 50.00 & $X$ & $\begin{array}{l}\text { Training programmes must } \\
\text { be organized in group to } \\
\text { reduce cost of cultivation. }\end{array}$ & 16 & 40.0 & VII \\
\hline 7. & $\begin{array}{l}\text { Middlemen } \\
\text { exploitation } \\
\text { marketing. }\end{array}$ & 25 & 62.50 & VI & $\begin{array}{l}\text { Collective marketing of } \\
\text { produce. }\end{array}$ & 21 & 52.50 & V \\
\hline 8. & $\begin{array}{l}\text { Lack of credit in times } \\
\text { of need. }\end{array}$ & 24 & 60.00 & $\begin{array}{l}\text { VII } \\
\text { I }\end{array}$ & $\begin{array}{l}\text { Encourage saving habit } \\
\text { among members. }\end{array}$ & 13 & 32.50 & $\begin{array}{l}\text { VII } \\
\text { I }\end{array}$ \\
\hline 9. & $\begin{array}{l}\text { Lack of storage } \\
\text { facilities. }\end{array}$ & 23 & 57.50 & IX & $\begin{array}{l}\text { Encouraging members to } \\
\text { establish and maintain } \\
\text { storage godowns. }\end{array}$ & 19 & 47.50 & IX \\
\hline 10. & $\begin{array}{l}\text { Lack of monitoring of } \\
\text { group activities by } \\
\text { leader. }\end{array}$ & 26 & 65.00 & $\mathrm{~V}$ & $\begin{array}{l}\text { Regular monitoring of } \\
\text { group activities by leader. }\end{array}$ & 32 & 80.00 & $X$ \\
\hline
\end{tabular}

Seventy per cent of respondents expressed few people dominate in group for which 62.50 per cent of respondents suggested homogeneity principle must be followed in group formation. Sixty seven and half per cent of respondents expressed lack of support from organisation to be organised into a group for which 75.00 per cent of respondents suggested support must be available to group to be organized into group. 65.00 per cent of respondents expressed lack of monitoring of group activities by group leader for which 80.00 per cent of respondents suggested leaders should monitor group activities.

Sixty two and half percent of respondents expressed exploitation of middlemen in market for which 52.50 per cent of respondents expressed collective marketing of produce. Sixty two and half per cent of respondents expressed lack of empowered leaders for which 72.50 per cent suggested 
continuous updating knowledge and skills of leader. Sixty per cent of respondents expressed lack of credit in times of need for which 32.50 per cent of respondents suggested saving habit needs to be encouraged.

Fifty seven and half per cent of respondents expressed lack of storage facilities for which 47.50 per cent of respondents expressed encourage members to establish and maintain storage godowns. Fifty per cent of respondents expressed lack of training programmes on reducing cost of cultivation for which 40.00 per cent of respondents suggested training programmes must be conducted on reducing cost of cultivation.

\section{References}

Sengere, R. W. 2009. Group cohesiveness in coffee farmer groups in Papua New
Guinea. PNG Coffee Journal.14 (1/2):11-26.

Shashi Vashisht., Kumud Khanna., Renu Arora and Nirmala Yadav. 2008. Dimensions of group dynamics effectiveness of self-help groups of rural women in Haryana. Indian Research Journal of Extension Education. 8(2).

Geethanjali, R and Prabhakar, K. 2013. Economic Development of women through self help groups in YSR district, Andhra Pradesh, India. Studies on Home and Community Science. 7(1):25-34.

Kalra, R. K. Anil, B. Tonts, M and Siddique, K. H. M. 2013. Self-help groups in Indian Agriculture: A case study of farmer groups in Punjab, Northern India. Agroecology and Sustainable Food Systems. 37(5):509-530.

\section{How to cite this article:}

Karthik, D., A. Sailaja, T. Archana and Gajanand Palve. 2017. Hindrances in Functioning of Farmer Groups in Telangana State, India. Int.J.Curr.Microbiol.App.Sci. 6(6): 2120-2124. doi: https://doi.org/10.20546/ijcmas.2017.606.251 